\title{
PEMANFAATAN LAHAN PEKARANGAN SEBAGAI BENTUK PEMBERDAYAAN SOSIAL EKONOMI MASYARAKAT MELALUI USAHA BUDIDAYA LELE (Studi Kasus di Desa Salamredjo Kecamatan Sentolo, Kulon Progo, DIY)
}

\author{
Hertria Maharani Putri, Asnawi dan Yayan Hikmayani ${ }^{1}$ \\ ${ }^{1}$ Peneliti pada Balai Besar Riset Sosial Ekonomi Kelautan dan Perikanan \\ JI. KS Tubun Petamburan VI Jakarta 10260. \\ Telp. (021)53650162, Fax. (021)53650159 \\ Diterima 23 Maret 2010 - Disetujui 26 Juni 2010
}

\begin{abstract}
ABSTRAK
Penelitian ini menganalisa sistem usaha perikanan di Desa Salamredjo, Kecamatan Sentolo Kabupaten Gunung Kidul pada tahun 2009 dalam mendukung program ketahanan pangan. Penelitian ini bertujuan untuk memberikan gambaran potensi pemanfaatan lahan pekarangan sebagai lahan budidaya sebagai upaya pemberdayaan masyarakat. Metode penelitian yang digunakan yaitu metode survey dan responden dipilih secara sengaja (purposive). Pengambilan data primer dilakukan melalui wawancara semi terstruktur dengan menggunakan kuesioner. Hasil penelitian menunjukkan bahwa pemanfaatan lahan pekarangan untuk usaha budidaya ikan lele dapat menambah sumber pendapatan bagi keluarganya. Upaya ini juga meningkatkan peran sosial pembudidaya ikan dalam kehidupan bermasyarakat melalui pembentukan kelompok usaha yang akan memperkuat posisi tawar pembudidaya ikan.
\end{abstract}

Kata Kunci: pemanfaatan lahan pekarangan, pemberdayaan sosial ekonomi, budidaya lele

\section{Abstract: Utilization of Home-yard for Catfish Culture as a Means of Community Empowerment (Case Study of the Salamredjo Village, Sentolo Sub-District, Kulon Progo, Yogyakarta). By: Hertria Maharani Putri, Asnawi and Yayan Hikmayani}

This research analyzes fishery business system in Salamredjo Village, Sub district of Sentolo, Gunung Kidul in 2009 in supporting food security program. It aims to provide situational analysis on utilization of home yard as a pond culture for community empowerment program. This research applies survey method with selective purposive respondents to collect primary and secondary data. Semi-structured interview through questionnaire is an approach to collect primary data. The results of this research show that home yard utilization for catfish culture can increase family income. It can increase fish farmers' social role of fish farmers in society through the formation of independent business group that can increase bargaining position of fish farmers.

Keywords: home-yard utilization, socio-economic empowerment, catfish culture 


\section{PENDAHULUAN}

Kondisi pembangunan masyarakat masih dirasakan belum merata untuk seluruh masyarakat Indonesia. Hal ini membuat kondisi perekonomian masyarakatpun cukup beragam. Ketidakmerataan ini menuntut setiap kawasan harus mampu memberdayakan dirinya sendiri secara sosial maupun ekonomi tanpa harus menunggu kebijakan atau program yang dikeluarkan oleh pemerintah. Definisi dari pemberdayaan sosial ekonomi masyarakat adalah penguatan pemilikan faktor-faktor produksi, penguatan penguasaan distribusi dan pemasaran, penguatan masyarakat untuk mendapatkan gaji/upah/pendapatan yang memadai, dan penguatan masyarakat untuk memperoleh informasi, pengetahuan dan ketrampilan, yang harus dilakukan secara multi aspek, baik dari aspek masyarakatnya sendiri, mapun aspek kebijakannya. (Ginandjar, 1997)

Pemberdayaan masyarakat dengan tujuan untuk meningkatkan pendapatan, dapat dimulai dengan pemanfaatan potensi alam yang telah tersedia. Potensi sumber daya wilayah dapat menjadi sarana untuk meningkatkan kualitas kehidupan penduduk setempat. Sektor perikanan dapat dijadikan salah satu alternatif usaha dalam memberdayakan masyarakat. Dengan kemajuan teknologi budidaya ikan, kegiatan usaha budidaya ikan dapat dilakukan bahkan di lokasi yang ketersediaan airnya minim.

Pekarangan adalah sebidang tanah di sekitar rumah yang mudah di usahakan dengan tujuan untuk meningkatkan pemenuhan gizi mikro melalui perbaikan menu keluarga. Pekarangan sering juga disebut sebagai lumbung hidup, warung hidup atau apotik hidup (Van den Ban dan Hawkins, 1999). Pengelolaan pekarangan ini dapat dilakukan secara berkelompok sehingga mudah untuk pemeliharaan dan pemanenan hasilnya. Pengelolaan pekarangan dapat dilakukan dengan membuka usaha budidaya misalnya budidaya ikan yang mudah dipelihara dengan fasilitas yang minim. Oleh karena itu menarik untuk dicermati salah satu bentuk pemberdayaan masyarakat melalui pelaksanaan optimalisasi lahan pekarangan dengan menciptakan usaha budidaya dalam skala rumah tangga secara berkelompok.

Desa Salamredjo, Kecamatan Sentolo merupakan salah satu lokasi rawan pangan menurut kriteria Badan Ketahanan Pangan, Departemen Pertanian sampai dengan tahun 2008. Sementara itu, selama dua tahun terakhir usaha budidaya ikan telah menjadi alternatif usaha yang semakin menjanjikan. Jumlah rumah tangga yang mengusahakan budidaya ikan semakin meningkat selama dua tahun terakhir. Melalui makalah ini, ingin mengkaji manfaat budidaya lele di lahan pekarangan dari segi pemberdayaan masyarakat dan mengetahui penerapan pemanfaatan lele tersebut lahan pekarangan untuk usaha budidaya

\section{METODOLOGI}

\section{Lokasi dan Waktu Penelitian}

Lokasi penelitian mengambil tempat di Desa Salamredjo, Kecamatan Sentolo, Kulon Progo, Propinsi Daerah Istimewa Yogyakarta. Penelitian tersebut dilakukan selama bulan Juni 2009. Desa Salam Redjo dipilih sebagai desa penelitian karena termasuk desa dengan kategori miskin dan rawan pangan menurut Badan Ketahanan Pangan setempat.

\section{Jenis dan Sumberdata}

Metode penelitian yang digunakan dalam penelitian ini yaitu metode survey. Pengambilan responden dilakukan secara sengaja (purposive) terhadap pembudidaya ikan yang masih aktif berusaha. Data terdiri dari data primer dan sekunder. Data primer diperoleh melalui wawancara dengan responden yang menggunakan kuesioner yang terstruktur. Data sekunder diperoleh dari Dinas Perikanan dan Peternakan Kabupaten Kulon Progo, Badan Ketahanan Pangan Kabupaten Kulon Progo, jurnal nasional dan internasional, serta artikel-artikel dari media 
massa. Selain itu data sekunder diperoleh melalui laporan penelitian yang dilakukan sebelumnya.

\section{Pengolahan dan Analisis Data}

Data-data yang telah terkumpul, baik data primer dan sekunder ditabulasi dan kemudian dianalisis menurut kebutuhan dalam pembahasan. Pendekatan analisis dilakukan untuk melihat peran kelembagaan dalam pemberdayaan pembudidaya ikan yang akan dianalisis secara kualitatif dan untuk melihat keragaan usaha budidaya ikan dilakukan melalui pendekatan analisa usaha sederhana.

dimana :

$$
\Pi=\mathrm{TR}-\mathrm{TC}
$$

$\begin{aligned} \Pi= & \text { Pendapatan usaha pembesaran } \\ & \text { lele }(\mathrm{Rp}) / \text { Operating revenues rearing } \\ & \text { clarias sp. }(R p) \\ \mathrm{TR}= & \text { Penerimaan total usaha budidaya } \\ & \text { lele }(\mathrm{Rp}) / \text { Receipts total clarias } s p . \\ & \text { farming }(R p) \\ \mathrm{TC}= & \text { Total biaya usaha budidaya } \\ & \text { lele }(\mathrm{Rp}) / \text { The total cost of cultivation of } \\ & \text { clarias sp. }(\mathrm{Rp})\end{aligned}$

Analisis rasio pendapatan dan biaya digunakan untuk mengetahui sejauhmana hasil yang diperoleh dari kegiatan usaha selama satu siklus pemeliharaan cukup menguntungkan. Dengan menggunakan rumus:

\section{R/C Ratio $=$ TR $/ T C$}

Kriteria usaha yang digunakan adalah :

$\mathrm{R} / \mathrm{C}>1$, maka usaha tersebut menguntungkan $\mathrm{R} / \mathrm{C}<1$, maka usaha tersebut rugi

$\mathrm{R} / \mathrm{C}=1$, maka usaha dalam kondisi impas

\section{HASIL DAN PEMBAHASAN}

\section{Gambaran Umum Lokasi Penelitian}

Kabupaten Kulon Progo merupakan salah satu wilayah di Propinsi Daerah Istimewa Yogyakarta yang terletak paling barat dengan batas sebelah barat dan utara adalah Propinsi Jawa Tengah dan sebelah selatan adalah Samudera Indonesia. Luas wilayah $58.627,5$ Ha yang meliputi 12 kecamatan dan 88 desa. Dari luas tersebut $24,89 \%$ berada di wilayah Selatan yang meliputi Kecamatan Temon, Wates, Panjatan dan Galur, 38,16 \% di wilayah tengah yang meliputi Kecamatan Lendah, Pengasih, Sentolo, Kokap, dan 36,97 $\%$ di wilayah utara yang meliputi Kecamatan Girimulyo, Nanggulan, Kalibawang dan Samigaluh. Luas kecamatan antara 3.000 $7.500 \mathrm{Ha}$ dan yang wilayahnya paling luas adalah kecamatan Kokap seluas 7.379,95 Ha sedangkan yang wilayahnya paling sempit adalah kecamatan Wates seluas $3.200,239 \mathrm{Ha}$.

Di Kecamatan Sentolo terdapat beberapa desa yaitu Desa Banguncipto, Sentolo, Kaliagung, Salamredjo, Sukoreno, Tuksono, Demangrejo dan Srikayangan. Salah satu desa yaitu Desa Salamredjo yang memiliki luas $420 \mathrm{Ha}$ dengan populasi penduduk sebanyak 5.605 jiwa dan rumah tangga sebanyak 1.201. Desa Salamredjo selama dua tahun terakhir termasuk kedalam desa rawan pangan (Anonim, 2003).

Dari Data sekunder yang diperoleh menunjukkan bahwa penduduk Desa Salamredjo memiliki sumberdaya manusia yang cukup potensial. Usia rata-rata penduduk yaitu 36,7 \% berusia 25-34 tahun, dimana usia tersebut merupakan usia produktif. Dari sisi pendidikan, sebesar $56,7 \%$ penduduk tamat SLTA. Kedua potensi tersebut merupakan potensi yang dapat mendukung usaha berhasilnya program pemberdayaaan yang dilakukan.

Dari kondisi geografis, walaupun desa ini tergolong sulit air namun di beberapa lokasi terdapat sumber mata air yang cukup karena letaknya di dataran rendah atau daerah hilir dari Kabupaten Kulon Progo. Berbeda dari desa-desa seperti di Kecamatan Samigaluh yang berada di dataran tinggi sehingga kesulitan untuk mendapatkan air. Desa Salamredjo ini juga memiliki sumber air yang lebih baik bahkan dari desa tetangganya yaitu Desa Tuksono. Selama ini air yang ada digunakan untuk pengairan sawah. 
Luas lahan yang ada di Desa Salamredjo adalah 421,36 Ha. Dari jumlah tersebut, luas lahan yang digunakan untuk sawah dan budidaya masih kecil. Dari data BPS, dari keseluruhan luas lahan, sebesar 306,76 Ha lahannya digunakan untuk bangunan. Berikut tabel pengklasifikasian lahan sesuai dengan kegunaanya (Tabel 1).
Ikan lele dengan berbagai kemudahan dalam budidayanya sangat memungkinkan dapat dikembangkan di berbagai wilayah, baik di wilayah yang memiliki ketersediaan air cukup maupun di wilayah yang ketersediaan airnya kurang. Teknologi budidaya ikan lele juga terus berkembang mulai dari kolam tanah sampai pada kolam terpal. Budidaya ikan lele pada kolam terpal menjadi alternatif bagi

Tabel 1. Klasifikasi Lahan berdasarkan Jenis Lahan di Desa Salamrejo Tabel 1. Land Classification Based on the Types of Land in Salamrejo Village

\begin{tabular}{clcc}
\hline No & \multicolumn{1}{c}{ Jenis Lahan/ Type of Land } & $\begin{array}{c}\text { Potensi/ Potential } \\
\text { (Ha) }\end{array}$ & $\begin{array}{c}\text { Penggunaan } \\
\text { Optimal/Optimal } \\
\text { Utilization (Ha) }\end{array}$ \\
\hline 1 & Sawah/Rice field & 75,08 & 67 \\
2 & $\begin{array}{l}\text { Budidaya/Aquaculture (terdiri dari lahan } \\
\text { kering, lahan pekarangan dan } \\
\text { lainnya/Including dry lands, yards and other) }\end{array}$ & 38,19 & 0,8 \\
\hline
\end{tabular}

Sumber Badan Pusat Statistik, 2008/ Source Statistics Central Beaureau, 2008

Keragaan Usaha Budidaya Lele (Clarias sp)

Perkembangan budidaya ikan Lele (Clarias sp.) selama lima tahun terakhir menunjukkan perkembangan yang semakin meningkat. Dari Tabel 2 dapat dilihat perkembangan produksi ikan lele hasil budidaya selama lima tahun terakhir serta perbandingannnya dengan produksi total ikan budidaya.

Dari data pada tabel 2 menunjukkan bahwa budidaya ikan lele telah menjadi pilihan pembudidaya ikan sat ini. Hal ini sangat beralasan karena permintaaan pasar terhadap ikan lele juga terus meningkat. wilayah yang ketersediaan airnya kurang memadai. Disamping itu budidaya ikan lele pada kolam terpal dapat dijadikan sebagai usaha pemanfaatan lahan pekarangan rumah yang menghasilkan pendapatan tambahan bagi keluarga.

Kemudahan budidaya ikan lele dalam pembudidayaannya menjadi pilihan penting dalam pemilihan komoditas usaha budidaya ikan. Budidaya lele tidak memerlukan persyaratan khusus yang terlalu rumit dan hasilnya pun sangat menguntungkan. Adapun persayaratan untuk mengelola budidaya lele (Khairuman. et.al, 2002):

Tabel 2. Perkembangan Produksi Ikan Lele Hasil Budidaya di Indonesia Tahun 2005-2009 Table 2. Catfish Production in Indonesia Cultivation Results for Years 2005-2009

\begin{tabular}{lccccc}
\hline \multirow{2}{*}{$\begin{array}{c}\text { Jenis Ikan/ } \\
\text { Types of Fish }\end{array}$} & $\mathbf{5}$ & \multicolumn{5}{c}{ Tahun/ Year } \\
\cline { 2 - 5 } & $\mathbf{2 0 0 5}$ & $\mathbf{2 0 0 6}$ & $\mathbf{2 0 0 7}$ & $\mathbf{2 0 0 8}$ & $\mathbf{2 0 0 9}$ \\
\hline $\begin{array}{l}\text { Ikan Lele/Catfish } \\
\text { Produksi Total/ }\end{array}$ & 67529 & 75142 & 88405 & 103293 & 137747 \\
Total Production & 331962 & 381945 & 410373 & 479167 & 554067 \\
\hline
\end{tabular}

Sumber: Statistik Perikanan Budidaya, Dirjen Perikanan Budidaya, 2009 /

Source: Aquaculture Statistics, Directorate General of Aquaculture, 2009 
1. Tanah yang baik untuk kolam pemeliharaan adalah jenis tanah liat/lempung, tidak berporos, berlumpur dan subur. Lahan yang dapat digunakan untuk budidaya lele dapat berupa: sawah, kecomberan, kolam pekarangan, kolam kebun, dan blumbang.

2. Ikan lele hidup dengan baik di daerah dataran rendah sampai daerah yang tingginya maksimal $700 \mathrm{~m} \mathrm{dpl}$.

3. Elevasi tanah dari permukaan sumber air dan kolam adalah 5-10\%.

4. Lokasi untuk pembuatan kolam harus berhubungan langsung atau dekat dengan sumber air dan tidak dekat dengan jalan raya.

5. Lokasi untuk pembuatan kolam hendaknya di tempat yang teduh, tetapi tidak berada di bawah pohon yang daunnya mudah rontok.

6. Ikan lele dapat hidup pada suhu $20^{\circ} \mathrm{C}$, dengan suhu optimal antara $25-28^{\circ} \mathrm{C}$.

7. Sedangkan untuk pertumbuhan larva diperlukan kisaran suhu antara $26-30^{\circ} \mathrm{C}$ dan untuk pemijahan $24-28^{\circ} \mathrm{C}$.

8. Ikan lele dapat hidup dalam perairan agak tenang dan kedalamannya cukup, sekalipun kondisi airnya jelek, keruh, kotor dan miskin zat $\mathrm{O}^{2}$.

9. Perairan tidak boleh tercemar oleh bahan kimia, limbah industri, merkuri, atau mengandung kadar minyak atau bahan lainnya yang dapat mematikan ikan.

10.Media air yang banyak mengandung zat-zat yang dibutuhkan ikan dan bahan makanan alami. Tempat yang digunakan tidak rawan banjir.

Kecamatan Sentolo dikategorikan sebagai desa miskin rawan pangan oleh Badan Ketahanan Pangan setempat. Desa Salamredjo Kecamatan Sentolo, Kulon Progo yang merupakan desa rawan pangan dengan persentase jumlah rumah tangga miskin tertinggi yaitu sebesar $67,57 \%$, kini oleh Pemerintah Kabupaten Kulon Progo ditunjuk sebagai desa Mandiri Pangan. Salah satu langkah yang dilakukan untuk mengentaskan kemiskinan adalah dengan mengusahakan suatu aktivitas yang menguntungkan dan dapat juga berguna sebagai sumber konsumsi masyarakat. Oleh karena pilihan pengembangan budidaya ikan lele di Desa Salamredjo sangatlah tepat. Budidaya ikan lele di Desa Salamredjo telah berkembang sejak dua tahun terakhir dan telah berhasil memberikan matapencaharian alternatif bagi masyarakat di desa tersebut.

Aktivitas usaha budidaya ikan lele dilakukan dengan mengoptimalkan lahan pekarangan. Pemanfaatan lahan pekarangan untuk usaha budidaya ikan lele dapat bermanfaat disamping sebagai upaya peningkatan gizi keluarga dengan penyediaan konsumsi ikan mandiri, juga dapat memberikan sumbangan pendapatan bagi keluarga. Di Yogyakarta pekarangan umumnya dapat memberikan sumbangan pendapatan antara $7 \%$ sampai dengan $45 \%$. Selain itu, tingkat konsumsi ikan di Kecamatan Sentolo cukup tinggi namun kebutuhan ikan untuk konsumsi masyarakat masih disediakan dari daerah lain.

Konsumsi ikan di Kabupaten Kulonprogo cukup tinggi. Hal ini terlihat dari data jumlah ikan yang masuk serta keluar daerah di setiap kecamatan serta jumlah ikan yang dikonsumsi pada tahun 2007 , seperti yang dapat dilihat pada Tabel 3.

Dari tabel 3 menunjukkan bahwa Kecamatan Sentolo termasuk kedalam wilayah yang memiliki kebutuhan ikan untuk konsumsi masyarakatnya tergolong cukup besar. Sementara itu pasokan ikan selama ini diperoleh dari luar wilayah. Atas dasar data tersebut, maka harus dilakukan pengembangan usaha budidaya ikan di lokasi tersebut untuk pemenuhan kebutuhan konsumsi ikan bagi masyarakatnya.

Pengembangan usaha budidaya ikan yang sangat memungkinkan dengan kondisi di lokasi yaitu budidaya ikan lele dengan menggunakan kolam terpal. Kolam terpal memiliki beberapa kelebihan. Dari hasil wawancara dengan responden, beberapa keuntungan budidaya ikan lele di kolam terpal, antara lain: 
Tabel 3. Perdagangan ikan Menurut Kecamatan di Kabupaten Kulon Progo Tahun 2007 Tabel 3. Fish Trade by sub Districs in Kulon Progo District, 2007

\begin{tabular}{rlrrr}
\hline No & Kecamatan/District & $\begin{array}{c}\text { Jumlah Ikan } \\
\text { Masuk/Number } \\
\text { of Fish In (Kg) }\end{array}$ & $\begin{array}{c}\text { Ikan Keluarl } \\
\text { Number of } \\
\text { Fish Out (Kg) }\end{array}$ & $\begin{array}{c}\text { Ikan yang } \\
\text { dikonsumsi/ } \\
\text { Consumption } \\
\text { Fish (Kg) }\end{array}$ \\
\hline 1. & Sentolo & 205.882 & 24.566 & 181.316 \\
2. & Girimulyo & 69.531 & 36.764 & 32.767 \\
3. & Nanggulan & 133.119 & 15.777 & 117.342 \\
4. & Samigaluh & 33.070 & 5.424 & 27.646 \\
5. & Kalibawang & 93.501 & 17.456 & 76.045 \\
6. & Lendah & 212.565 & 22.898 & 189.667 \\
7. & Pengasih & 192.193 & 6.748 & 185.445 \\
8. & Kokap & 44.335 & 10.879 & 33.456 \\
9. & Temon & 188.791 & 25.766 & 163.025 \\
10. & Wates & 231.641 & 28.674 & 202.967 \\
11. & Panjatan & 149.144 & 15.256 & 133.888 \\
12. & Galur & 211.376 & 28.767 & 182.609 \\
& Jumlah & $\mathbf{1 . 7 6 5 . 1 4 8}$ & $\mathbf{2 3 8 . 9 7 5}$ & $\mathbf{1 . 5 2 6 . 1 7 3}$ \\
\hline
\end{tabular}

Sumber: Badan Pusat Statistik, 2007/ Source Statistic Berau Center, 2007

1. Modal relatif kecil

2. Perawatan yang relatif mudah

3. Daya tahan kolam 1-4 tahun

4. Bahan baku pembuatan kolam mudah didapatkan

5. Waktu pembuatan kolam yang relatif cepat

6. Masa pengeringan kolam lebih cepat

Namun demikian, kekurangan kolam terpal yaitu: penanganan khusus karena harus dilakukan pergantian air secara berkala, karena sisa pakan dan kotoran ikan tidak terurai karena kolam tidak bersentuhan dengan tanah. Penggantian air dilakukan dua kali selama satu siklus budidaya. Pertama pada saat lele ikan berumur 50 hari dan kedua pada 10 hari berikutnya. Apabila penggantian air tersebut dilakukan dengan baik maka kematian lele paling tinggi hanya mencapai $10 \%$.

Modal yang digunakan untuk membuat satu buah kolam lele berkisar antara Rp. 150.000,--hingga Rp. 250.000,-tergantung dari bahan pembuat kolam, apakah menggunakan bambu, bata atau hanya dikeruk saja. Kebutuhan permodalan untuk usaha budidaya ikan lele di kolam terpal secara lebih rinci dapat dilihat pada Table 4.

Dari perhitungan analisa usaha menunjukkan bahwa usaha budidaya ikan lele yang dilakukan oleh masyarakat sangat menguntungkan. Bahkan saat dilakukan survey ini budidaya ikan lele telah berkembang pesat bahkan mampu menjual produksi hasil budidayanya sampai ke desa sekitar seperi ke Desa Tuksono.

Kegiatan budidaya ikan lele telah terbukti dapat menyumbang pendapatan keluarga serta pemenuhan gizi keluarga yang bersumber dari protein hewani.

Dari gambaran yang ada di Desa Salamredjo, dapat dijadikan masukan bagi pengembangan program-program terkait dengan pemberdayaan serta peningkatan kesejahteraan di lokasi rawan pangan lainnya.

\section{Pembentukan dan Pengembangan Aksi Kolektif Kelompok Budidaya}

Pemberdayaan melalui pengembangan aksi kolektif dapat diartikan sebagai pengembangan koperasi atau kelompok 


\section{Tabel 4. Analisa Usaha Budidaya Ikan Lele dengan Kolam Terpal per Petak per Siklus di Desa Salamredjo, Kecamatan Sentolo, DIY, 2009}

Table 4. Business Analysis with the Catfish Culture in Ponds sheeting per Plot per Cycle in the Village Salamredjo, District Sentolo, DIY, 2009

\begin{tabular}{lcr}
\hline \multicolumn{1}{c}{ Uraian/Description } & Jumlah/Total & Nilai/Value \\
\hline $\begin{array}{l}\text { Investasi/Investment: } \\
\text { Pompa/Pump }\end{array}$ & 1 buah @ Rp.225.000 & 225.000 \\
Kolam terpal/Pond & 1 buah @Rp.250.000 & 250.000 \\
$\begin{array}{l}\text { Biaya opersional/ } \\
\text { Operating costs }\end{array}$ & & \\
Benih/Seed & 1.000 ekor @ Rp.100 & 100.000 \\
$\begin{array}{l}\text { Pakan/Feed } \\
\text { Produksi/Production }\end{array}$ & $90 \mathrm{~kg} @$ Rp.6.700 & 603.000 \\
Keuntungan/Fropit & $90 \mathrm{~kg}$ X Rp. 10.000 & 900.000 \\
\hline
\end{tabular}

Keterangan: Ukuran kolam per petak $\left(30 \mathrm{M}^{2}\right) /$ Remaks: The size of the pool $\left(30 \mathrm{M}^{2}\right)$

Lama pemeliharaan satu siklus usaha: 3-4 bulan/Length of fish culturein onecycle 3-4 mounths

usaha bersama. Pengembangan aksi kolektif dilakukan untuk membuka kesempatan kepada masyarakat membentuk kelompokkelompok yang diinginkan yang tidak sematamata koperasi atau kelompok usaha bersama. Aksi kolektif merupakan suatu aksi bersama yang bermuara pada kesejahteraan setiap anggota secara individu.

Penerapan budidaya di Desa Salamredjo berkembang cukup pesat setelah adanya pengembangan yang dibina oleh salah seorang warga desa Salamredjo tersebut. Dinas Perikanan setempat juga mempunyai peran yang cukup besar dalam pengembangan usaha budidaya. Di desa ini terdapat kelompok Mina Pokdakan (Kelompok Pembudidaya Ikan) yang memiliki 20 orang anggota. Ketua dari kelompok ini adalah seorang ibu rumah tangga yang saat ini mempunyai fungsi sebagai penyambung program-program yang dikeluarkan pemerintah ataupun pengetahuan yang diberikan oleh lembaga-lembaga non pemerintah yang berkepentingan dalam pengentasan kemiskinan ataupun berkepentingan dalam peningkatan peran budidaya perikanan.
Kelompok ini mempunyai agenda yaitu melakukan pertemuan setiap bulannya untuk membahas perkembangan usaha budidaya mereka dan juga mengadakan pertemuan dalam rangka program sosialisasi budidaya perikanan dari dinas penyuluhan setempat atau instansi lainnya. Dalam pertemuan tersebut, biasanya anggota kelompok pembudidaya ikan diberikan pengetahuan tentang teknologi atau cara berbudidaya yang lebih efektif sehingga dapat meningkatkan produksi ataupun keuntungan. Mereka juga dipertemukan dengan kelompok-kelompok pembudidaya lainnya sehingga dapat saling bertukar pengalaman dalam hal pengembangan usaha budidaya. Artinya dalam usaha budidaya yang dilaksanakan secara berkelompok ini, setiap anggota dapat memperoleh akses informasi seputar budidaya ikan, akses mendapatkan pengetahuan dan ketrampilan dan juga akses untuk berpartisipasi dalam organisasi sosial.

Pemberdayaan lain juga terlihat dari contoh di Desa Salamrejo, dengan adanya kelembagaan yang jelas dan terdaftar ini, masyarakat akan mudah untuk mengakses sumber-sumber keuangan. Sumber keuangan 
yang dapat diperoleh baik secara internal yaitu gotong royong dalam hal keuangan yang dilakukan sesama anggota kelompok ataupun akses terhadap sumber keuangan yang sifatnya eksternal seperti pinjaman ke bank.

Dalam pembentukan kelompok ini, tiap anggota juga diberdayakan secara politik. Artinya, setiap pemikiran atau pendapat dari tiap-tiap anggota, dibicarakan dalam forum reguler yang diadakan secara berkala oleh kelompok. Selain itu, suara dari kelompok dapat dilanjutkan ke instansi terkait untuk dapat didengar dan menjadi bahan masukkan bagi pengembangan usaha .

\section{Kendala yang Masih Dihadapi oleh Pembudidaya}

Pemberdayaan masyarakat melalui usaha budidaya ikan lele serta penguatan kelembagaan dapat terus dioptimalkan. Namun demikian, ada beberapa kendala yang akan menjadi hambatan yang masih perlu untuk ditanggulangi. Beberapa kendala tersebut diantaranya yaitu:

1. Ketersediaan benih ikan untuk kebutuhan budidaya masih didatangkan dari luar, sehingga kualitas serta asal usus benih tidak diketahui. Disamping itu karena lokasi penghasil benih jauh dengan lokasi maka harga benih yang diterima pembudidaya cukup mahal karena biaya transportasi serta kematian ikan. Sampai saat survey dilakukan baru satu orang saja yang melakukan pembenihan ikan lele di lokasi.

2. Ikan untuk konsumsi untuk Desa Salamredjo masih sebagian besar didatangkan dari luar wilayah. Hal ini menyebabkan harga ikan konsumsi relatif mahal.

3. Inovasi atau proses alih teknologi budidaya ikan cukup lambat. Teknologi yang diperlukan saat ini untuk pengembangan budidaya ikan lele yaitu teknologi intensifikasi budidaya yang bertujuan untuk meningkatkan produktivitasnya.

4. Sumberdaya manusia yang terampil dan menguasai teknologi budidaya masih terbatas. Padahal dari sisi yang lain penduduk di desa ini memiliki kualitas pendidikan rata-rata SLTA dan perguruan tinggi, sehingga akan memudahkan untuk mentransfer teknologi dengan baik.

5. Pengelolaan usaha budidaya ikan saat ini masih tradisional dan bersifat sambilan. Matapencaharian utama masyarakat di lokasi yaitu sebagai supir angkutan, buruh pabrik furniture ataupun buruh kerajinan tas anyaman.

6. Biaya pembelian pakan ikan untuk budidaya mencapai $60 \%$ dari total biaya yang dikeluarkan untuk budidaya ikan. Sementara itu harga pakan terus meningkat dan menyebabkan beban biaya pakan ini cukup berpengaruh dalam usaha budidaya ikan lele.

\section{IV.KESIMPULAN DAN IMPLIKASI KEBIJAKAN}

Pemanfaatan lahan pekarangan sebagai wadah untuk melakukan aktivitas budidaya ikan, ternyata telah mampu memberikan matapencaharian alternatif serta pendapatan bagi masyarakat di lokasi penelitian. Melalui usaha buiddaya ikan lele dikolam terpal yang berada di pekarangan rumahnya memberikan pendapatan satu siklus usaha sebanyak Rp. 297.000,- untuk setiap petak. Disamping itu, melalui budidaya ikan maka pemenuhan gizi keluarga miskin dapat terpenuhi dari sumber hewani tanpa membayar karena disediakan sendiri.

Penguatan kelembagaan baik kelembagaan produksi, pemasaran, permodalan sangatlah penting dalam usaha pemberdayaan masyarakat. Melalui kerjasama kolektif pelaku usaha memiliki posisi tawar lebih kuat.

\section{Implikasi Kebijakan}

Pemberdayaan masyarakat melalui usaha budidaya di lahan pekarangan perlu diinternalisasikan dalam pengembangan, perencanaan, serta pelaksanaan pengelolaan lahan pekarangan sebagai tempat budidaya secara terpadu baik yang dikembangkan oleh 
masyarakat itu sendiri maupun yang dirancang oleh pemerintah sebagai bentuk affirmative action. Kerjasama antara masyarakat dan pemerintah diharapkan dapat meminimalisir kendala yang masih muncul dalam pengembangan usaha budidaya berbasis pemanfaatan lahan pekarangan.

\section{DAFTAR PUSTAKA}

Annonimous. 2010. Statistik Perikanan Budidaya Indonesia Tahun 2009. Direktorat Jenderal Perikanan Budidaya. Kementerian Kelautan Perikanan 2003․ Peta Kerawanan Pangan

Indonesia. Badan Bimas Ketahanan Pangan Departemen Pertanian Jakarta. . 2003 ${ }^{\mathrm{b}}$. Buku Profil Penataan Ruang Propinsi Daerah Istimewa Yogyakarta, Departemen Permukiman dan Prasarana Wilayah Direktorat Jenderal Penataan Ruang, Wilayah Tengah. Jakarta
Bengen, D.G. 2001. Pengelolaan Sumberdaya Wilayah Pesisir Secara Terpadu, Berkelanjutan dan Berbasis Masyarakat. Makalah pada Sosialisasi Pengelolaan Sumberdaya Berbasis Masyarakat. Bogor, 21-22 September 2001.

Kartasasmita, G., 1997 "Pembangunan Sosial dan Pemberdaya n : Teori, Kebijaksanaan, dan Penerapan".

Khairuman dan Amri, Khairul, 2002. Budidaya lele Dumbo Secara Intensif. Agromedia Pustaka. Jakarta.

Van den Ban dan H.S. Hawkins. 1999. Penyuluhan Pertanian. Kanisius. Jakarta.

Warseno, Yus. 2004. Optimalisasi Lahan Untuk Pengembangan Budidaya Air Tawar Khususnya Pembenihan Udang Galah Skala Rumah Tangga. Dinas Peternakan, Kelautan dan Perikanan Kabupaten Bantul. 